\title{
PENDIDIK DALAM PENDIDIKAN ISLAM PADA MASYARAKAT
}

\author{
'Hasruddin Dute*, ${ }^{2}$ Zaidir \\ Universitas Yapis Papua Jayapura \\ hasruddindute@gmail.com \\ Korespondensi
}

Naskah diterima: 25 Januari 2021, direvisi: 30 Maret 2021, disetujui: 10 Juni 2021

\section{Abstrak}

Tulisan ini bertujuan untuk menjelaskan fungsi seorang pendidik di masyarakat. Pada dasarnya pendidikan Islam merupakan suatu proses yang berlangsung secara terus menerus dan mengalir ke dalam kehidupan manusia dan berlangsung sepanjang hayat. Tugas dan fungsi pendidikan ditujukan kepada anak sekolah yang berkembang dan berkembang secara dinamis dari isi sampai akhir hayat dan yang tidak dapat memisahkan keberhasilan pendidikan dari sisi pedagogis. Pendidik pada hakikatnya adalah orang yang diamanahkan yang bertanggung jawab atas dunia akhirat dengan mendidik, membimbing, membimbing dan menuntun peserta didik ke pintu gerbang kesuksesan baik dunia maupun akhirat. Untuk menjadi berkualitas dan profesional, kriteria dan persyaratan tertentu harus dipenuhi dalam konteks tujuan hidup dan juga kualitas yang harus dibawa oleh pendidik dalam melaksanakan tugasnya dan sebagai pendidik. Metode yang dipakai di dalam penelitian ini adalah penelitian kepustakaan, atau dapat digunakan dalam bahan pustaka sebagai sumber informasi untuk menjawab permasalahan tentang pendidik dalam pendidikan. Sebagai seorang pendidik seorang guru memainkan peran yang sentral bagi peserta didik. Peran guru dalam membina siswa agar menjadi manusia yang berkarakter sangat dibutuhkan. Pertama sebagai pendidik dan pengajar. Kedua sebagai pemberi keteladanan dan menjadi teladan. Ketiga, menjadi solusi di tengah-tengah masyarakat.

Kata Kunci: Pendidik; Pendidikan Islam.

\section{Abstrak}

This paper aims to explain the function of an educator in society. Basically, Islamic education is a process that takes place continuously and flows into human life and lasts a lifetime. The tasks and functions of education are aimed at school children who develop and develop dynamically from content to the end of life and who cannot separate educational success from the pedagogical side. Educators are essentially mandated people who are responsible for the hereafter by educating, guiding, guiding and guiding students to the gates of success in both the world and the hereafter. To be qualified and professional, certain criteria and requirements must be met in the context of the purpose of life and also the qualities that must be brought by educators in carrying out their duties and as educators. The method used in this research is library research, or can be used in library materials as a source of information to answer problems about educators in education. As an educator, a teacher plays a central role for students. The role of the teacher in fostering students to become human beings with character is very much needed. First as educators and teachers. Second, as an exemplary giver and a role model. Third, be a solution in the midst of society.

Keywords: Islamic Educator and Education 


\section{PENDAHULUAN}

Pemetaan masalah pendidikan yang menjadi hal yang penting dalam menguraikan benang kusut dunia pendidikan saat, apalagi pada wilayah Indonesia bagian Timur. Setidaknya tiga tema besar masalah pendidikan. Pertama, angka buta huruf yang masih ada. Kedua, penyediaan sarana dan prasarana yang kurang dan dialami oleh hampir semua sekolah. dan ketiga, persoalan literasi akibat rendahnya minat baca karena buku-buku yang ada kurang diminati siswa. ketiga masalah ini dapat diselesaikan dengan adanya guru yang dapat membimbing masyarakat agar menjadi pembelajar dan dapat membaca dunia.

Guru dalam pendidikan melakukan usaha sadar dan terencana untuk membuat suasana belajar dan proses pembelajaran agar tercipta individu yang berdayaguna untuk diri, keluarga, masyarakat dan negara. Pendidikan dalam Islam adalah sebuah proses mempelajari pengetahuan atau kemampuan dan keterampilan yang dimiliki oleh seseorang. Pendidikan merupakan hak wajib setiap warga negara, yaitu setiap warga negara berhak menyampaikan dan membagi ilmunya serta memperoleh ilmunya. Sebagaimana dinyatakan dalam UUD 1945 Pasal 31 Ayat 1 bahwa "Setiap warga negara berhak atas layanan pendidikan". Dalam mewujudkan agar semua mendapatkan layanan pendidikan maka pemerintah juga mengeluarkan kebijakan selama 12 tahun warga negara wajib belajar. Namun pada kenyataannya dalam proses pelaksanaan pendidikan tidak didukung oleh infrastruktur yang memadai dan tenaga pendidik yang tidak menetap lama. Apalagi untuk daerah yang sulit dijangkau dengan kendaraan darat.

Proses pembelajaran, guru tidak hanya menjalankan fungsi pemberi ilmu pengetahuan (transfer of knowledge) tapi juga berfungsi untuk menanam nilai (value) serta membangun karakter (character building) peserta didik secara berkelanjutan dan berkesenambungan. Kalau kita lihat secara terminologi, peran dan fungsi merupakan manifestasi dari sifat ketuhanan. Demikian mulianya posisi guru, sampai Allah Swt, dalam pengertian sebagai rabb mengidentifikasi diriNya sebagai rabbul'alamin Sang Maha Guru seluruh jagad raya. Orang yang telah mempunyai ilmu pengetahuan memiliki kewajiban mengajarkannya kepada orang lain. Profesi guru dalam menyebarkan ilmu pengetahuan merupakan infestasi ibadah.

Guru sebagai penanggung jawab pendisiplinan siswa harus mengontrol setiap aktivitas siswa-siswa agar tingkat laku siswa tidak menyimpang dengan norma-norma yang ada. Selain kewajiban mengajar juga merupakan profesi dalam meningkatkan 


\section{Jurnal Kajian Agama Hukum dan Pendidikan Islam \\ (KAHPI)}

p-ISSN 2685-8401 e-ISSN 2685-7502

kompetensi kualifikasi akademik. Apabila dilakukan oleh orang yang bukan ahlinya maka tunggulah kehancuranmu. Hadist Rasulullah Saw. yang dijadikan pegangan oleh guru.

Tugas-tugas ini berkaitan dengan meningkatkan pertumbuhan dan perkembangan siswa untuk mengalamanpengalaman lebih lanjut seperti penggunaan kesehatan jasmani, bebas dari orang tua dan orang dewasa yang lain, moralitas tanggungjawab kemasyarakatan, pengetahuan dan keterampilan dasar, persiapan untuk perkawinan dan hidup berkeluarga, pemilihan jabatan dan hal-hal yang bersifat personal dan spritual. Oleh karena itu tugas dan fungsi guru dapat disebut pendidik.

Tenaga pendidik yang ditempatkan di tanah Papua masih belum signifikan jumlahnya. Di samping itu bertahan dalam kondisi geografis Papua yang masih jauh dari fasilitas membuat guru tidak dapat bertahan lama di tempat tugas. Usaha yang dilakukan oleh pemerintah dengan mengutus orang Papua sebagai pendidik dan menyekolahkan di tanah Jawa dengan maksud agar setelah selesai dari sekolah dapat membangun daerah masing-masing belum dapat sepenuhnya terlaksana. Walaupun banyak masyarakat yang dikenal sebagai sarjana muda, hal ini tidak menggambarkan wajah pendidikan masyarakat, karena masyarakat yang telah lulus pendidikan meninggalkan wilayah asalnya dengan motivasi yang besar untuk berkarir di luar daerah sehingga belum juga secara signifikan masalah guru dapat terselesaikan. Padahal keberadaan guru menjadi ujung tombak dalam peningkatan pendidikan.

\section{METODE PENELITIAN}

Melihat permasalahan pendidikan di Papua, kuncinya terletak pada minimnya tenaga pendidik di Papua sehingga terdapat masyarakat yang tidak mengenyam pendidikan dengan baik. Maka metode yang dipakai di dalam penelitian ini adalah penelitian kepustakaan, atau dapat digunakan dalam bahan pustaka sebagai sumber informasi untuk menjawab permasalahan tentang pendidik dalam pendidikan. Tahapan yang dilakukan adalah mengumpulkan bahan yang terkait, kemudian bahan tersebut dikaji, dibaca, dituangkan dalam tulisan. Setelah itu semua selesai barulah data dianalisis dengan content analisis sehingga dapat ditarik kesimpulan terkait pendidik di dalam pendidikan Islam di tanah Papua.

\section{PEMBAHASAN}

Permasalahan pendidikan, tidak bisa berdiri sendiri, setidaknya harus ada guru, harus ada siswa, sarana prasana harus ada, lingkungannya ini merupakan masalah pertama terkait pendidikan di Papua. namun untuk dapat mengelola dan mengefisiensikan kegiatan pendidikan maka perlu adanya pengelola pendidikan yang secara sistemik 


\title{
Jurnal Kajian Agama Hukum dan Pendidikan Islam (KAHPI)
}

\author{
p-ISSN 2685-8401 e-ISSN 2685-7502
}

mengorganisir kegiatan pendidikan. Guru menjadi poin utama dalam pelaksanaan pendidikan di tanah Papua.

\section{A. Guru sebagai Pendidik}

Pendidik dalam pendidikan agama Islam adalah orang yang bertanggung jawab atas perkembangan peserta didik dengan mewujudkan seluruh potensi, mental, afektif, kognitif, dan psikomotoriknya ke arah yang lebih baik secara seimbang sesuai dengan nilai-nilai Islam (Yunus, Nurseha, 2020). AlQur'an sebagai sumber pertama ajaran Islam memainkan peran yang luar biasa dalam kehidupan seorang muslim jika ia dapat menerjemahkan firman Allah ke dalam kehidupan sosial. Dalam aspek pendidikan khususnya, banyak pelajaran yang bisa diambil serta referensi sahih dari ayat-ayat Allah. Ada juga pemahaman tentang pendidik di dalam al-Qur'an.

Pendidik sering disebut sebagai ustadz, muallim, mudarris, murabbi, mursyid. Pendidik adalah pelita segala zaman, mereka yang hidup dengannya, akan menerima pancaran cahaya ilmiah. Jika tidak ada pendidik di dunia, manusia akan lebih buruk dari hewan, karena apa yang dilakukan di dalam pendidikan adalah upaya untuk menjauhkan manusia dari perbuatan seperti hewan. Lebih lanjut beliau mengatakan bahwa dalam Islam orang yang paling bertanggung jawab adalah orang tua (ayah dan ibu) siswa. Tanggung jawab ini paling tidak disebabkan oleh dua hal: pertama, oleh kodratnya, yaitu karena orang tua ditakdirkan untuk bertanggung jawab atas pendidikan anakanaknya; Kedua, karena kepentingan kedua orang tua, yaitu orang tua berkepentingan terhadap kemajuan perkembangan anaknya, maka keberhasilan anaknya juga merupakan keberhasilan orang tuanya.

Pendidikan merupakan masalah yang penting dan telah menjadi konsen bagi masyarakat luas, sehingga pemerintah senantiasa berupaya dalam meningkatkan mutu pendidikan dengan harapan dapat menghasilkan lulusan yang memenuhi harapan masyarakat dan memiliki kualitas dalam kepribadian, akhlak, intelektualitas dan kualifikasinya (Yunus, 2021). Serta dapat beriman dan bertakwa baik itu program pelatihan dan pendidikan untuk pendidik dan tenaga kependidikan maupun melalui peningkatan berbagai standar nasional pendidikan.(Parda, Kohar, Tinggi, \& Islam, 2021)(Toyibatin, 2021).

Orang tua di dalam pendidikan memainkan peran sangat signifikan bagi anak. Kelanjutan penguatan pendidikan diwujudkan melalui pendidikan pada usia anak sekolah. Pendidikan anak di sekolah juga bertujuan untuk memadukan ilmu dan amalan ibadah, mengembangkan motivasi dan sikap, menguasai keterampilan dan memperkuat karakter anak. Kualitas penawaran pendidikan tidak hanya bergantung pada konsep, tetapi 


\section{Jurnal Kajian Agama Hukum dan Pendidikan Islam \\ (KAHPI)}

p-ISSN 2685-8401 e-ISSN 2685-7502

juga pada pendidik yang memiliki kemampuan dan kemauan untuk mencapai kinerja terbaik. Tanpa pendidik yang memadai dan efektif, program pendidikan yang didasarkan pada konsep yang cerdas dan dirancang tidak akan berhasil. karena itu, pentingnya mendidik anak dalam pendidikan harus menjadi perhatian dan peran serta pemerintah, lembaga pendidikan, orang tua dan masyarakat.(Irma, Nisa, \& Sururiyah, 2019).

Guru sebagai pendidik menempati menempati posisi yang penting dalam lslam. hal ini dapat dilihat dari penyebutan pendidik dalam al-Qur'an dengan sebutan murabbi dan mu'alim. Sumber tersebut dapat dijumpai pada surat al-Fatihah ayat 2 dan surat alBaqarah ayat 31. Dalam surat al-Fatihah ayat 2 dikatakan آلحَمْدُ لَِهِ رَبِّ الْعَالَمَيْنَ bahwa Allah adalah Tuhan semesta alam. Kata rabba yang berarti "menjaga, mendidik dan memelihara". lstilah yang digunakan dalam ayat ini adalah Rabb, derivasinya adalah tarbiyah (pendidik dan pengasuh), dan pelakunya adalah murabbi. Oleh karena itu, dalam konteks ayat ini, Allah swt. bertindak sebagai murabbi bagi alam semesta. Oleh karena itu, makna surah al-Fatihah ayat 2 bisa menjadi Segala puji bagi Allah, Pemelihara/Pendidik bagi alam semesta.

Sُعَلَّمَ آَدَمَ 31 disebutkan bahwa Allah mengajarkan nama-nama segala sesuatu kepada Adam. lstilah yang digunakan dalam ayat ini adalah

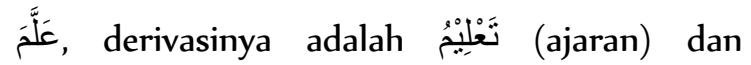

pelakunya adalah مُعَلِّم. Oleh karena itu, dalam ayat ini, Allah swt. Apakah Mu'allim untuk Adam as. al-Qur'an menyebut para pendidik dengan nama murabbi.

Nabi menggunakan istilah lain selain dari kedua istilah di atas yaitu ta'dib. dan pelakunya disebut dengan mu'addib. Istilah ta'dib didasarkan pada hadits Nabi, Allah telah mendidik saya (آَبَنَّي رَبِي) dengan pendidik terbaik (فَاَحْسنَ تَادْيْبِاً ) dan Hadits Nabi lainnya, yaitu jika membesarkan anak, maka berilah pendidikan yang baik. Dengan demikian, dalam hadits Nabi, pendidik disebut juga dengan mu'addib.

Guru adalah pendidik yang disebutkan di dalam referensi agama dengan nama Muallim, Murabbi dan Muaddib. Ketiganya merepresentasikan seorang guru yang membimbing dan menuntun peserta didik agar menjadi orang yang baik, menjadi pribadi yang paripurna serta dapat menjadi manusia yang dapat menjaga dan melestarikan kehidupan di dunia.

\section{B. Tugas Pendidik}

Tugas pendidik dalam pendidikan Islam adalah membimbing dan mengenali kebutuhan atau kemampuan peserta didik, menciptakan situasi yang kondusif bagi berlangsungnya proses pendidikan, menambah dan mengembangkan ilmu yang dimiliki untuk ditransformasikan kepada siswa, dan selalu membuka diri terhadap segala kelemahan atau 


\title{
Jurnal Kajian Agama Hukum dan Pendidikan Islam (KAHPI)
}

\author{
p-ISSN 2685-8401 e-ISSN 2685-7502
}

kekurangannya. (AKBAR, 2021). (Hasan, 2021). (Wahyu Tuti, 2021).

Unsur yang saling kait mengkait dalam proses pendidikan yaitu adanya guru, adanya ilmu dan adanya peserta didik. Guru sebagai pribadi yang menjembatani sampainya ilmu kepada peserta didik tanpa guru, peserta didik tidak akan memperoleh ilmu. Bagitu juga seorang guru yang tanpa adanya murid maka ilmu yang telah dimiliki menjadi tidak bermanfaat dan lebih berbahaya lagi bila ilmu yang tidak ada gurunya maka dapat menyesatkan murid. Maka begitulah unsur yang saling membutuhkan antara satu dengan lainnya. salah satu unsur penting di dalam pendidikan adalah unsur guru, karena dipundaknya terdapat tanggung jawab yang besar yang dicita-citakan. Hal ini dikarenakan pendidikan merupakan kumpulan kepribadian yang bersifat dinamis ke arah suatu perubahan secara terus menerus, sebagai sasaran vital untuk membangun kebudayaan dan peradaban manusia. (Anam \& Amri, 2020).

Pendidik dalam pendidikan merupakan aktivitas vital dalam upaya meningkatkan sumber daya manusia melalui transfer ilmu pengetahuan, keahlian dan nilai-nilai kehidupan demi memberikan pengetahuan bagi peserta didik menuju kedewasaan dan kematangan pribadinya. (Muvid, 2020).

Tugas guru sebagai seorang pendidik bukan hanya mereka yang mengajar di sekolah. Guru adalah pendidik yang dengan tulus mendidik dan mengajar ke generasi penerus. (Uhbiyati \& Ahmadi, 1997). Ada kesamaan pemahaman konsep para ahli dalam dunia pendidikan Islam dan Barat mengenai tugas dan fungsi guru sebagai pendidik. Pendidikan formal, guru mempunyai tugas sebagai pengajar, pendamping dan pelatih. Sebagai tenaga profesional, tugas pokok dan fungsi pendidik dirasakan sangat kompleks, karena tidak terbatas pada proses pendidikan di dalam kelas, tetapi juga berperan sebagai administrator, pembimbing dan evaluator. Dalam pendidikan, pendidik memberikan isi, motivasi berupa teguran atau peringatan, pujian, hukuman, pemberian contoh.(S, Muslimah, Riadi, \& Mukmin, 2021).

Guru merupakan unsur penting di dalam memegang peranan utama dalam proses belajar mengajar. Dimana proses terjadi mengandung serangkaian perbuatan guru dan siswa atau dasar hubungan timbal balik yang berlangsung dalam situasi edukatif untuk mencapai tujuan. Seorang guru mempunyai banyak tugas yang harus dikerjakan.(Sanjani, 2020). Ada tiga jenis tugas utama yang diemban oleh pendidik: (1) tugas di bidang profesi, yang meliputi pendidikan pengembangan, pengajaran ilmu pengetahuan dan teknologi, dan pelatihan siswa untuk memperoleh keterampilan. (2) Tugas di bidang kemanusiaan, dimana pendidik tidak hanya berperan sebagai pengganti orang tua peserta didik, tetapi juga menanamkan 


\title{
Jurnal Kajian Agama Hukum dan Pendidikan Islam \\ (KAHPI)
}

\author{
p-ISSN 2685-8401 e-ISSN 2685-7502
}

motivasi dan kasih sayang kepada peserta didiknya, sebagaimana ia mencintai anaknya sendiri demi tercapainya tujuan pembelajaran dan (3) tugas-tugas di bidang sosial yaitu menjadi solusi bagi setiap permasalahan sosial yang terjadi disekitarnya (Marlina, 2017).

Pendidik atau guru harus memiliki kompetensi dasar keilmuan yang akan disampaikan kepada siswa baik dari segi materi maupun metode yang diterapkan dalam proses pembelajaran. Jika guru tidak memiliki kompetensi untuk memberikan pengetahuan kepada siswa dan tidak mampu menerapkan metode pendidikan Islam dalam mengajar, bagaimana siswa dapat mengembangkan fitrah (sifat dan potensinya) sesuai dengan visi dan misi dalam pendidikan. Guru harus memiliki penguasaan materi maupun penerapan metode pendidikan Islam merupakan syarat utama yang harus menjadi perhatian pengelola pendidikan Islam.

Tugas dari seorang pendidik dirauikan sebagai berikut yaitu:

1. Guru sebagai profesi yaitu mendidik dan mengajar.

Tugas pertama pendidik adalah mengajar semua peserta didik terkait dengan pengetahuan yang mereka ketahui secara mendalam. Dalam kaitannya dengan tugas mengajar, seorang pendidik diharapkan mampu menyampaikan materi yang tertulis dalam buku atau media lain kepada siswa, sehingga nantinya siswa yang bersangkutan dapat menerapkan ilmu yang telah diperolehnya dalam kehidupan seharihari.(Almujtaba, Mangkurat, \& Profesi, 2021). Mengajar adalah sebuah profesi yang mulia yang dengannya mengajarkan kebaikan kepada orang lain.

Berdasarkan Undang-Undang Rl Nomor 14 Tahun 2005 tentang Guru dan Dosen Pasal 1, guru adalah pendidik profesional dengan tugas pokok mendidik, mengajar, membimbing, mengarahkan, melatih, menilai, dan mengevaluasi peserta didik pada pendidikan anak usia dini melalui pendidikan formal, pendidikan dasar, dan pendidikan menengah.(Ariani, 2021). (Saputri, 2021).

Guru sebagai pendidik adalah orang yang paling banyak bergaul dan berinteraksi dengan siswa dibandingkan dengan personel lain di sekolah. Guru bertugas merencanakan dan melaksanakan proses pembelajaran, menilai hasil pembelajaran, melakukan bimbingan dan pelatihan, melakukan penelitian dan penilaian, serta membuka komunikasi dengan masyarakat, menggerakkan dan mendorong siswa agar semangat belajar, sehingga semangat belajar siswa benar-benar dapat menguasai bidang ilmu yang sedang dipelajari. dipelajari.(Wekke, 2017).(Arista, 2020).

Belajar adalah tugas dari peserta didik dimana seorang kebiasaan belajar yang baik ini dapat menjadikan dirinya mencapai prestasi optimal. Kebiasaan belajar merupakan 


\title{
Jurnal Kajian Agama Hukum dan Pendidikan Islam (KAHPI)
}

\author{
p-ISSN 2685-8401 e-ISSN 2685-7502
}

merupakan salah satu faktor penentu akan keberhasilan peserta didik di dalam pembelajaran hal ini terjadi karena adanya hubungan kuat antara keinginan untuk mengetahui dan suasana yang mendukung dari sekitar.(Kasih, Suryadi, \& Triyono, 2021). Proses belajar mengajar merupakan inti dari proses pendidikan secara keseluruhan dengan guru sebagai pemegang peranan utama. Proses belajar mengajar mengandung serangkaian perbuatan pendidik dan siswa atas dasar hubungan timbal balik yang berlangsung dalam situasi edukatif untuk mencapai tujuan. (Johar \& Hanum, 2021)

Kesulitan belajar terjadi juga diri seorang peserta didik disebabkan oleh ketidakmampuan belajar yang dikenal sebagai gangguan belajar, gangguan belajar, kinerja buruk, lambat belajar, dan ketidakmampuan belajar. Gangguan belajar adalah situasi di mana proses belajar anak / siswa / siswa terganggu oleh hilangnya jawaban yang saling bertentangan. Terjadinya kesulitan belajar pada anak karena reaksi yang saling bertentangan dalam diri anak. (Dute, 2019) Dengan demikian, hasil belajar yang dicapai lebih rendah dari potensinya. Misalnya, anakanak yang terbiasa dengan olahraga keras seperti karate dan tinju. Maka akan sulit untuk menuntut gerakan yang anggun. Ketidakmampuan belajar Hal tersebut merupakan gejala dari proses belajar anak yang tidak berjalan dengan baik. Padahal anak tersebut sebenarnya tidak memiliki gangguan jiwa atau gangguan jiwa lainnya. Lambat belajar merupakan lambat dalam menerima atau menangkap pelajaran sehingga membutuhkan waktu lebih lama. Ketidakmampuan belajar ini dimana anak mengalami kesulitan belajar yang mengacu pada gejala dimana anak tidak dapat belajar sama sekali atau menghindari belajar. Sehingga tidak pernah tercapai hasil belajar intelektual. (Utami, 2020). (Dute, 2020).

Tugas seorang guru dalam menghadapi permasalahan ini dengan mendidik dan mengajar.(Marlina, 2020) Guru merupakan faktor penting yang sangat mempengaruhi proses dan hasil belajar bahkan menentukan berhasil tidaknya siswa dan pembelajaran. Begitu juga dengan pengembangan pembentukan karakter yang menuntut aktivitas, kreativitas dan karakter guru dalam rangka membentuk kompetensi pribadi peserta didik. Tugas guru tidak hanya menyampaikan informasi kepada siswa, tetapi juga harus dilatih menjadi fasilitator yang tugasnya memberikan kesempatan belajar kepada seluruh siswa agar mereka dapat belajar tentang diri mereka sendiri dengan cara yang menyenangkan, gembira, energik, dan cepat. Hal ini merupakan modal dasar bagi siswa untuk tumbuh dan berkembang menjadi manusia yang siap beradaptasi, menghadapi berbagai peluang, tantangan dan persaingan. (Aslamiah, 2020). 


\title{
Jurnal Kajian Agama Hukum dan Pendidikan Islam \\ (KAHPI)
}

\author{
p-ISSN 2685-8401 e-ISSN 2685-7502
}

2. Mendidik Peserta Didik Tugas kemanusiaan sebagai orang Tua

Tugas pendidik selanjutnya adalah mendidik anak didiknya. Seorang pendidik berkewajiban memberikan contoh kepada peserta didik untuk mengubah perilaku dan karakternya menjadi lebih baik. Kemudian dampak positif yang muncul adalah pola pergaulan dari siswa itu sendiri yang dapat membedakan mana yang baik dan mana yang buruk bagi dirinya. Guru sering dikonotasikan sebagai kepanjangan dari kata "digugu dan ditiru”. Digugu artinya apapun yang diajarkan guru selalu diyakini, didengar, diikuti dan diambil kebenarannya oleh semua siswanya. Teladan guru sangat penting karena apa yang dilakukan guru baik dari segi tingkah laku, perkataan maupun perbuatan menarik perhatian siswa. Hal ini karena pendidik adalah figur terbaik dalam hal pandangan, tata krama, dan tindakan anak, terlepas dari apakah siswa sadar sedang ditiru atau tidak. Teladan pendidik akan menunjukkan gejala identifikasi positif, yaitu persamaan dengan orang yang ditiru. (Sun'iyah, 2020)(Fatmawati, 2020).

Rasulullah saw. menjadi orang yang diteladani yang perbuatannya menjadi figur sentral untuk diteladani. Oleh karena itu, Islam mengakui bahwa cara yang paling efektif untuk mencapai keberhasilan terbesar dan untuk menyampaikan nilai-nilai ajaran lslam secara lebih efisien adalah dengan menjadi panutan. Oleh karena itu, sangat diyakini bahwa ada hubungan antara keteladanan guru dan kepribadian peserta didik. Para siswa menjadikan guru sebagai panutan di sekolah oleh karena itu guru harus dapat memberikan contoh bagi siswa dalam lingkungan sekolah. (Mardiah, 2020) (Rosyid, 2020).

Keteladanan yang dicontohnya oleh seorang pendidik telah dapat membentuk karakter peserta didik ke arah yang lebih baik. Dukungan dari pihak sekolah di dalam membentuk karakter peserta didik telah dapat mempengaruhi pembentukan kebiasaan baik yang dimiliki sehingga peran guru yang juga sebagai orang tua di sekolah dapat dilakukan dengan baik. (Haniyyah, 2021).

3. Guru sebagai Solusi bagi Masyarakat

Keadaan Sekitar.

Sebagai anggota masyarakat guru juga berperan di dalam membimbing dan membina masyarakat dimana ia tinggal. Sebagai agen dari masyarakat, guru berperan sebagai penengah di antara masyarakat. guru membawa dan mengembangkan berbagai upaya pendidikan di lingkungan sekolah dan juga membawanya di dalam kehidupan di masyarakat. (Mustafa, 2020). (Sholich, 2020).

Kedudukan sebagai teladan dan fungsi tanggung jawab moral di masyarakat menjadi tugas yang berat. Hal ini terjadi karena secara tidak langsung guru bertanggung jawab atas generasi bangsa dimana peserta didik juga berada di dalam lingkungan yang sama dengan 


\title{
Jurnal Kajian Agama Hukum dan Pendidikan Islam
}

(KAHPI)

\author{
p-ISSN 2685-8401 e-ISSN 2685-7502
}

guru. How to be a great teacher dalam dilihat dari jiwa dan ruhnya seorang guru yang mana tidak hanya menjadi teladan di tempat mengajar namun juga menjadi panutan di tengah tengah masyarakat luas. (Sanjani, 2020). Keteladanan seorang di guru di masyarakat memberikan dampak yang nyata terhadap kepribadian anak di masa yang akan datang maka seharusya para guru juga berkualitas di dalam diri maupun di luar diri. Menjadi seorang pengajar dan juga menjadi seorang pendidik baik dan juga menjadi teladan. (Siwi, 2020).

Tugas sebagai seorang pendidik adalah menjadi seorang pengajar, menjadi orang tua peserta didik selama berada sekolah, dan menjadi solusi bagi masyarakat sekitar. Ketiga hal ini harus ada pada diri seorang pendidik sehingga hasil dari didikannya dapat menjadikan peserta didik sebagai masyarakat yang baik, yang tangguh dan dapat berdaya guna untuk diri keluarga, bangsa dan negara.

\section{Kesimpulan.}

Sebagai seorang pendidik seorang guru memainkan peran yang sentral bagi peserta didik. Peran guru dalam membina siswa agar menjadi manusia yang berkarakter sangat dibutuhkan. Pertama sebagai pendidik dan pengajar. Kedua sebagai pemberi keteladanan dan menjadi teladan. Ketiga, menjadi solusi di tengah-tengah masyarakat. Berdasarkan fungsi dari pendidik tersebut maka seorang guru harus mempunyai pengetahuan dalam mendidik, menjadi teladan, dan menjadi bagian solusi di tengah masyarakat. Keberhasilan pendidikan karakter sangat tergantung pada peran seorang guru dalam proses pembelajaran. Sehingga sosok guru dapat menjadi cerminan siswa yang sangat menentukan karakternya. Menciptakan suasana kondusif dalam proses belajar mengajar sangat membantu dalam menanamkan karakter anti kekerasan. Penerapan disiplin yang diterapkan guru dalam tata tertib kelas berpengaruh terhadap keberhasilan proses pembelajaran agar tercipta suasana belajar yang kondusif. Melalui suasana belajar yang kondusif, memudahkan siswa dalam memahami materi pelajaran.

\section{DAFTAR PUSTAKA}

AKBAR, T. (2021). Pendidik dalam Pendidikan Islam (Religius-Rasional) Studi Tokoh Mohammad Natsir dan Harun Nasution. UIN Raden Intan Lampung.

Almujtaba, P. W., Mangkurat, U. L., \& Profesi, A. K. (2021). Guru dan profesionalitas dalam pendidikan. 1(2), 1-10.

Anam, K., \& Amri, A. (2020). Pendidik dalam Perspektif Pendidikan Islam. Akademika: Jurnal Keagamaan Dan Pendidikan, 16(1), 86-94.

Ariani, N. (2021). Profesi Keguruan. PUBLIKASI PEMBELAJARAN, 1(2), 68-72.

Arista, O. (2020). Komitmen guru sertifikasi dalam melaksanakan tugas mengajar di Sekolah Menengah Atas Negeri Kecamatan Pauh Padang. Jurnal Bahana Manajemen Pendidikan, 2(1), 542-549.

Aslamiah, S. (2020). KESULITAN BELAJAR BAHASA INGGRIS DALAM PERSPEKTIF PENDIDIKAN. PrimEarly: Jurnal Kajian Pendidikan Dasar Dan Anak Usia Dini, 3(2), 134-146. 


\title{
Jurnal Kajian Agama Hukum dan Pendidikan Islam (KAHPI)
}

\author{
p-ISSN 2685-8401 e-ISSN 2685-7502
}

Dute, H. (2019). Kebijakan Pemerintah Terhadap Pendidikan Agama di Sekolah Umum Pra Kemerdekaan dan Pasca Kemerdekaan. 309. 3(1), 309-331.

Dute, H. (2020). Peranan Lingkungan Keluarga dan lingkungan Sekolah Terhadap Pembentukan Akhlak Slswa. Jurnal Kependidikan Dan Keagamaan, 4(1), 303318.

Fatmawati, E. (2020). Kerjasama Orang Tua Dan Guru Dalam Meningkatkan Motivasi Belajar Peserta Didik. IBTIDA', I(2), 135150.

Haniyyah, Z. (2021). Peran Guru PAl dalam Pembentukan Karakter Islami Slswa di SMPN 03 Jombang. Irsyaduna: Jurnal Studi Kemahasiswaaan, 1(1), 75-86.

Hasan, 1. (2021). Tugas Pendidik Dalam AlQuran. Universitas Islam Negeri Sumatera Utara.

Irma, C. N., Nisa, K., \& Sururiyah, S. K. (2019). Keterlibatan Orang Tua dalam Pendidikan Anak Usia Dini. Jurnal Obsesi: Jurnal Pendidikan Anak Usia Dini, 3(1), 214. https://doi.org/10.31004/obsesi.v3il.152

Johar, R., \& Hanum, L. (2021). Strategi Belajar Mengajar: Untuk Menjadi Guru yang Profesional. Syiah Kuala University Press.

Kasih, F., Suryadi, S., \& Triyono, T. (2021). Kolaborasi Pendidik Dan Peserta Didik Dalam Proses Belajar Mengajar Pada Masa New Normal. Wahana Dedikasi: Jurnal PkM Ilmu Kependidikan, 4(1), 4662.

Mardiah, F. (2020). Analisis kandungan buku sirah nabawiyah tentang suri teladan nabi muhammad saw untuk membina karakter siswa di MI. UIN Sunan Gunung Djati Bandung.

Marlina. (2017). Pendidik dalam Konteks Pendidikan Islam. Al l'tibar, 3(1), 27-40.

Marlina, R. (2020). Identifikasi kesulitan belajar sains dan upaya yang dilakukan guru sekolah menengah untuk mengatasinya. Jurnal Pendidikan Informatika Dan Sains, 9(1), 13-20.

Mustafa, M. S. (2020). Pengabdian Tanpa Pamrih Tangguru Jahido'untuk Masyarakat Pangkep. PUSAKA, 8(1), 1-20.
Muvid, M. B. (2020). Konsep Pendidikan Agama Islam Dalam Tinjauan Hadits (Studi Analisis Tentang Hadits-Hadits Pendidikan). Tarbawiyah: Jurnal Ilmiah Pendidikan, 4(1), 1-27.

Parda, A., Kohar, A., Tinggi, S., \& Islam, A. (2021). Strategi Kepala Sekolah dalam Mengembangkan Profesionalisme dan Kompetensi Tenaga Pendidik di Ma AlHidayah. 1(2), 163-182.

Rosyid, U. S. (2020). METODE PEMBELAJARAN DALAM PERSPEKTIF NABI MUHAMMAD SHALLALLAHU 'ALAIHI WASALLAM. Jurnal Aksioma AdDiniyyah: The Indonesian Journal of Islamic Studies, $8(1)$.

S, M. T., Muslimah, M., Riadi, A., \& Mukmin, M. (2021). Implikasi pedagogis al-Qur'an surah Al-Ahzab ayat 45-48 mengenai tugas dan fungsi guru sebagai pendidik. Ta'dibuna: Jurnal Pendidikan Islam, 1O(1), 13.

https://doi.org/10.32832/tadibuna.v10il.418 8

Sanjani, M. A. (2020). Tugas dan Peranan Guru Dalam Proses Peningkatan Belajar Mengajar. Serunai: Jurnal Ilmiah Ilmu Pendidikan, 6(1), 35-42.

Saputri, 1. (2021). KEPRIBADIAN GURU MENURUT KI HAJAR DEWANTARA DAN RELEVANSINYA DENGAN UNDANG-UNDANG TENTANG GURU DAN DOSEN DAN PENDIDIKAN ISLAM. IAIN Bengkulu.

Sholich, M. (2020). Peranan Guru Agama Islam Dalam Meningkatkan Religiusitas Siswa Di Era Digital. Jurnal Ats-Tsaqofi, 2(1), 85-95.

Siwi, K. (2020). PROGRAM KEMITRAAN MASYARAKAT (PKM) PENINGKATAN KEMAMPUAN MENGAJAR UNTUK GURU-GURU SD DI KECAMATAN TOMOHON TENGAH KOTA TOMOHON. ABDIMAS: JURNAL PENGABDIAN KEPADA MASYARAKAT, $13(2)$.

Sun'iyah, S. L. (2020). Sinergi Peran Guru dan Orang Tua Dalam Mewujudkan Keberhasilan Pembelajaran PAl Tingkat Pendidikan Dasar di Era Pandemi Covid- 
19. DAR EL-ILMI: Jurnal Studi Keagamaan, Pendidikan Dan Humaniora, $7(2), 1-16$.

Toyibatin, S. (2021). Peningkatan Kinerja Guru Melalui Pelatihan Berkelanjutan Sebagai Upaya Pengembangan Kualitas. 1/(1), 1-10.

Uhbiyati, N., \& Ahmadi, A. (1997). llmu Pendidikan Islam (IPI) untuk Fakultas tarbiyah Komponen MKDK. Cet. $l$. Bandung: Pustaka Setia.

Utami, F. N. (2020). Peran Guru dalam Mengatasi Kesulitan Belajar Siswa Sekolah Dasar. EDUKATIF: JURNAL ILMU PENDIDIKAN, 2(1), 93-100.

Wahyu Tuti, M. (2021). KONSEP PENDIDIKAN ISLAM ANAK UISIA DINI MENURUT ABDULLAH NASHIH ULWAN (TELAAH TANGGUNG JAWAB PENDIDIK DALAM KITAB TARBIYATUL AULAD FIL ISLAM). IAIN Purwokerto.

Wekke, 1. S. (2017). Integrasi Pendidikan Islam. Fenomena, 9(1), 103-110. https://doi.org/10.48094/raudhah.v2il.17

Yunus, Nurseha, M. (2020). Culture of Siri' in Learning Akidah Akhlak in MAN Suli Luwu District Budaya Siri dalam. JIEBAR: Journal of Islamic Education: Basic and Applied Research, ol, 107-120.

Yunus, Y. (2021). Education in Learning Religious Education in College Education in Palopo City. Journal on Education, O3(02), 186-195. Retrieved from https://jonedu.org/index.php/joe/article/vi ew/349 